\title{
Total diz protezi sonrası instabilite
}

\section{Instability following total knee arthroplasty}

\author{
İbrahim Akel ${ }^{1}$, Bülent Atilla ${ }^{2}$ \\ ${ }^{1}$ İzmir Kent Hastanesi, Ortopedi ve Travmatoloji Bölümü; İzmir Ekonomi Üniversitesi, Sağlık Bilimleri Fakültesi, İzmir \\ ${ }^{2}$ Hacettepe Üniversitesi Tıp Fakültesi, Ortopedi ve Travmatoloji Anabilim Dalı, Ankara
}

\begin{abstract}
Total diz protezi işlemi, ileri gonartroz tedavisinde etkin ve hasta memnuniyeti açısından tatmin edici bir tedavi yöntemidir. Total protez sonrası ilk beş yılda ortaya çıkan başarısız sonuçlar arasında, enfeksiyondan sonra ikinci sırada, protez instabilitesi yer alır. Hastalar çoğu kez fonksiyonel ağrıdan, ara ara artan ılımlı bir şişlikten şikâyet ederler. En ağır tablo diz çıkığıdır ve çok nadir olarak ortaya çıkar. Instabilitenin esas kaynağını ortaya koymak genellikle zor olup, iyi bir hikâye alma ve ayrıntılı hasta değerlendirmesi gerektirir. Instabilitenin ortaya konmasında çoğu kez, basarak çekilen grafiler veya stres grafileri gibi dinamik radyolojik değerlendirmeler gerekmektedir. İnstabilite tedavisi çoğunlukla diz protezinin revizyonunu gerektirmekle beraber, esas nedenin ortaya konmasındaki zorluklar nedeniyle revizyon cerrahisi sonrası instabilitenin devam etme oranı \%30'lara kadar varabilmektedir. Bu nedenle, primer ve revizyon cerrahiler sırasında yumuşak doku dengesi, dengeli kemik kesisi yapılması ve uygun implant tipinin seçimine özen göstermek, deneme protezleri ve kalıcı protezler yerleştirildikten sonra instabiliteye yönelik intra-operatif muayeneyi dikkatle yapmak gerekmektedir.
\end{abstract}

Anahtar sözcükler: diz protezi; instabilite; komplikasyonlar
Total knee arthroplasty is an effective and satisfactory way of treating severe gonarthrosis. Instability is the second most common complication of total knee arthroplasty, following infection, in first five years of the procedure. Patients mostly complain about a functional pain and undulating mild swelling around the joint. The most dramatic scene is dislocation of the prosthesis; which is a very rare condition. Finding the underlying cause of the instability requires a detailed history taking and patient evaluation. Weight bearing plain radiographies and dynamic radiological procedures like stress radiographs are mostly needed to diagnose the instability. Treatment is mostly by the revision of prosthesis whereas difficulty in diagnosis of the main mechanism under the instability yields up to $30 \%$ insisting instability following revision surgeries. Thus, surgeon should be particular about soft tissue balance, symmetrical bone cuts, choosing appropriate implant type in index and revision procedures and must perform instability tests intraoperatively with trials and definitive components.

Key words: knee arthroplasty; instability; complications
D iz osteoartritinin cerrahi tedavisinde total diz protezi, \%90'ın üzerinde 10 yıllık sağkalım oranı ile güvenilir ve başarılı bir yöntemdir. Total diz protezi işleminden sonraki beş yılda başarısız sonuçlar arasında en sık enfeksiyon ve instabilite görülürken, revizyon nedenleri arasında instabilite görülme oranı \%10 ile \%22 arasında değişmektedir. ${ }^{[1-4]}$

Total diz protezi sonrası instabilite, hareket ve yük verme ile ağrı, anormal ses gelmesi şikâyeti ve bazen de şekil bozukluğu ile kendini gösteren, protezin beklenen sınır ve planların ötesinde hareket etmesine bağlı bir durumdur. Klinik kötü sonuç olarak kabul edilen instabilitenin en ileri aşaması diz çıkığı olmakla beraber, diz protezi sonrası çıkık görülme oranı $\% 0,5$ 'in altındadır. ${ }^{[5-7]}$

Diz protezinde instabilitenin tedavisi çoğu kez cerrahi olup, revizyon cerrahisi sonrası halen devam eden instabilite oranı \%8-36 arasında değişmektedir ve bu yüksek oran, sıklıkla instabilitenin ve nedeninin doğru şekilde ortaya konulamamasından kaynaklanır. ${ }^{[4,6,7]}$

Günümüzde total diz protezi uygulamasında en sık kullanılan teknik "gap (aralık) eşitliği" tekniğidir. Bu teknikte, bağ dengesi ve alt ekstremite "mekanik aksına dik” kesilerle mekanik aks üzerinde bir dizilim sağlanır.

- İletişim adresi: Dr. Bülent Atilla, Hacettepe Üniversitesi Tıp Fakültesi, Ortopedi ve Travmatoloji Anabilim Dalı, 06100 Sıhhiye, Ankara Tel: 0532 - 2928717 e-posta: batilla@gmail.com

- Geliş tarihi: 19 Aralık 2018 Kabul tarihi: 19 Aralık 2018 
Dizin fizyolojik yüklenme şekline uyulmamakla beraber, protez yüzeyler, yerleştirildikleri anatomik bölgenin mekanik aks çizgilerine dik olarak konulur ve böylece aşınmanın önüne geçilir; daha en baştan instabil bir eklem oluşturulacağı kabul edilmiş olur; çünkü, anatomik alt ekstremite diziliminde tibia platosu ile femoral kondiller mekanik aks ortalama $3^{\circ}$ açı yapar. Bu prensiplere sadık kalınarak uygulanan diz protezi sonrası kabul edilmiş instabilite içerisinde hastaların memnuniyeti oldukça yüksektir. Teknik olarak uygun total diz protezlerinde bile \%18-20 oranında ağrı görülebilmesinin nedeni de bu olabilir. Bu "gap eşitliği” tekniğindeki instabilitenin önüne geçmek üzere desteklenen ve yeni bir kavram olarak sunulan "kinematik teori" ile, doğal alt ekstremite biyomekaniğini tekrar etme prensibi gözetilmektedir. ${ }^{[8]}$

$\mathrm{Bu}$ bölümde primer diz protezi sonrası tibio-femoral instabilitenin tanısı ve tedavisini tartışacağız. Patellofemoral instabilite, daha sonraki bölümlerde ele alınacağı için bu bölümde değerlendirilmeyecektir.

\section{TANI VE DEĞERLENDIRME}

Total diz protezi sonrası instabilitenin klinik olarak ortaya konması ve tedavi planı için hastanın şikâyeti ve öyküsü ayrıntılı olarak sorgulanmalı, ilk cerrahiden önceki muayene bulguları, klinik, radyolojik değerlendirme notları, ilk cerrahinin teknik notu, kullanılan protezin tipi, cerrahi sonrası rehabilitasyon süreci ve varsa travmaları araştırılmalıdır. Hastalar sıklıkla yerini, şeklini tam tarif edemedikleri, hareketle ortaya çıkan bir ağrıdan şikâyet ederken, nadiren instabilitenin en ağır şekli olan posterior çıkık ile gelirler. Fizik muayene, radyolojik ve laboratuvar bulguları ışığında instabilite tanımlandıktan sonra tedavi planlanmalıdır. ${ }^{[2,5,9]}$

Hasta sıkça, belli hareket aralıklarında yüklenme ile ağrı, boşluk hissi ya da anormal sürtünme veya çarpma sesinden şikâyet ederken, dizinde şekil bozukluğu veya şişlik tarif edebilir.

Fizik muayenede hastanın yürüyüşü ve oturduğu yerden kalkışı sorunun kökeni hakkında oldukça fazla ipucu verecektir. Hastanın otururken ve oturduğu yerden kalkmaya çalışırken diz hareketleri ve ağrısı, patolojik hareketler, yürüme sırasında her planda ekstremitenin dizilimi, yine dinamik değerlendirme açısından varusa, valgusa kayma ve rekurvatum gelişip gelişmediği dikkatle gözlenmelidir. Fleksiyon, midfleksiyon instabilitelerinde oturduğu yerden kalkma sırasında ön diz ağrısı tipiktir. Oturduğu yerden kalkma ve yürümenin değerlendirildiği muayene sonrası hastanın oturur ya da yatar pozisyonda eklem dizilimi, şişlikler, insizyon skarı, cilt bulguları, hareket açıklı̆̆ı, $0^{\circ}, 15^{\circ}$, $30^{\circ}, 60^{\circ}, 90^{\circ}$ ve tam fleksiyonda koronal ve sagittal

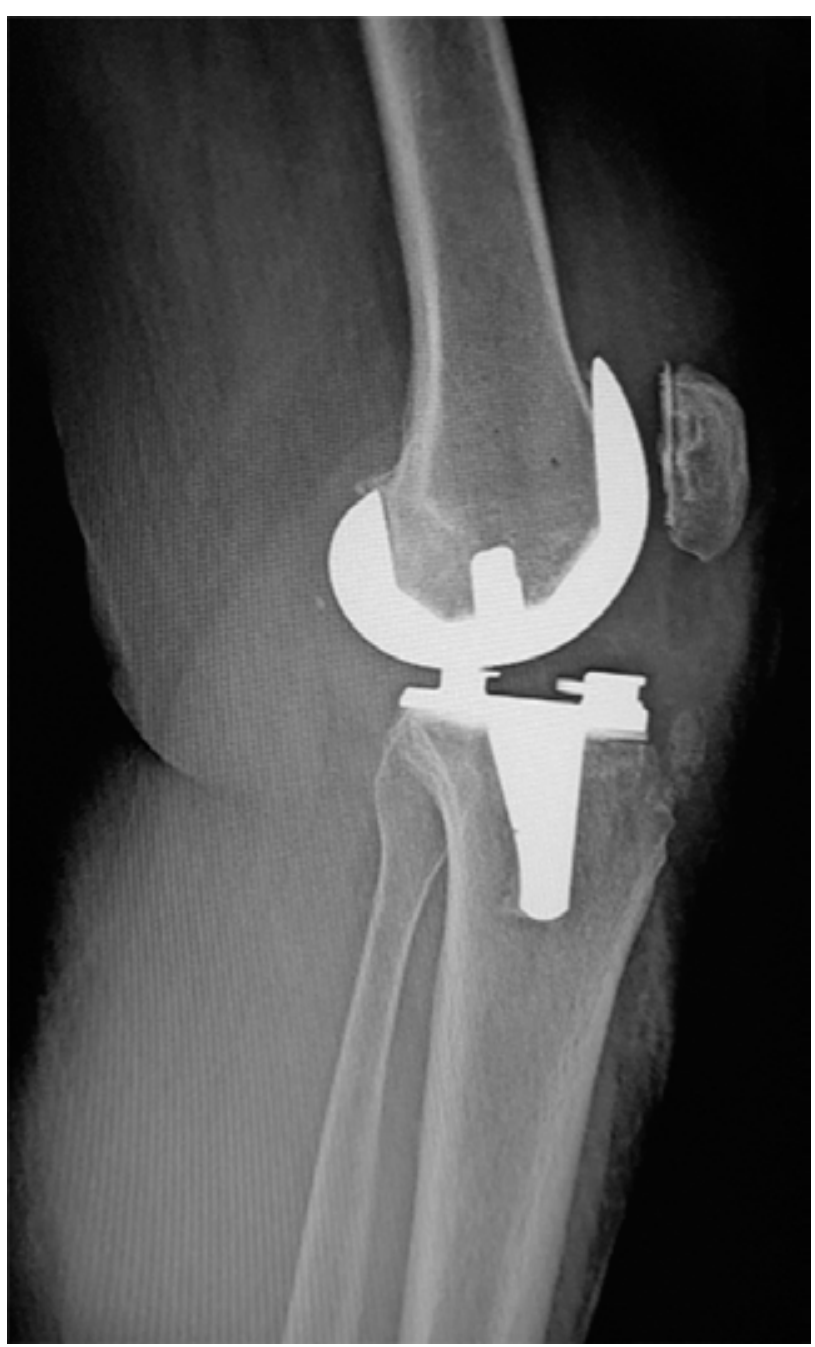

Şekil 1. Total diz protezi sonrası basarak lateral grafide anterior translasyon görülmektedir.

planda instabilite ile kas kuvvetleri değerlendirilmelidir. Özellikle fleksiyon instabilitelerinde diz anteromediyalinde ve pes anserin tendonları üzerinde hassasiyet ve şişlik gözlenir. İnstabiliteye bağlı sinovit ve sinoviyal hipertrofi, diz çevresi şişlik ve effüzyon olarak kendini gösterir. ${ }^{[2,4-7]}$

Radyolojik incelemelerde standart, yatarak ön-arka ve yan grafilerin yanı sıra tam ekstansiyon ve tam fleksiyon grafileri ile beraber stres grafileri (varus, valgus, ön, arka çekmece, tek ayak üstü yüklenme) instabilitenin değerlendirilmesinde önemlidir; dizilim ve dinamik açılanmaların yanı sıra lateral grafilerde instabilite yönünde translasyon değerlendirilebilir (Şekil 1). Bilgisayarlı tomografi (BT), aksiyel plan komponent rotasyonunun değerlendirilmesi için gereklidir; komponent rotasyonları hem tibiofemoral 
hem patellofemoral instabilite açısından önemlidir. Enfeksiyon ve aseptik gevşeme ayırıcı tanıları için sintigrafik inceleme yararlı olabilir. ${ }^{[1,2,4-7]}$

Tam kan sayımı, eritrosit sedimentasyon hızı, C-reaktif protein gibi kan testleri ve eğer yapılmışsa eklem ponksiyon örneklerinin mikroskopisi ve bakteri kültürü çalışması, enfeksiyon ve aseptik gevşemenin değerlendirilmesi açısından gereklidir. Fleksiyon instabilitelerinde, kan testlerinde enfeksiyon bulgularına rastlanmazken, patolojik eklem hareketine bağlı gelişen travmatik ve reaktif sinovite bağlı kronik effüzyonların aseptik hemorajik içeriği tipiktir.

\section{Sınıflandırma}

Diz protezinin stabilitesi, kemik ve yumuşak doku dengesine bağlıdır. Bu nedenle, klinik instabilitenin tanımında tüm bunları içeren bir sınıflandırmaya ihtiyaç duyulur. Uygun bir sınıflandırma, instabilitenin görüldüğü hareket aralığı ve yönü üzerine bilgi vermeli, böylece instabilitenin beklenen gidişatı ve düzeltilmesi gereken esas sorunu işaret edebilmelidir. Song ve ark.'nın önerdiği sınıflandırma bu ihtiyaca uygun görünmekte$\operatorname{dir}\left(\right.$ Tablo 1). ${ }^{[4]}$

\section{Risk Faktörleri}

Illk cerrahisinden önce deformitesi fazla olan; ekstra-artiküler veya yürüme ile ortaya çıkan dinamik deformitesi, genel ya da bölgesel kas zayıflı̆̆ı olan; arka çapraz bağı olmayan; sistemik hastalıklara veya nöromusküler sorunlara bağlı mekanik ya da yumuşak doku tutulumuna bağlı iç yan bağ, arka çapraz bağ yetmezlik geliştirme riski olan hastalarda; obez hastalarda ve "gap-aralık" dengesi uygun şekilde sağlanmayan hastalarda, diz protezi ameliyatı sonrası instabilite görülme riski daha fazladır.

İleri deformitesi olanlarda cerrahi sırasında fazla miktarda yapılması gereken yumuşak doku gevşetmeleri ve bu sırada iç yan bağın işlevsiz hale gelmesi nedeniyle, total diz protezi sonrası instabilite daha sık görülmektedir. Dinamik deformitesi olanlarda ise sıkılığını kaybetmiş bağ yapısı, protez sonrası instabiliteye katkıda bulunur.

Genel ya da bölgesel kas zayıflığına bağlı olarak dizini rekurvatumda kilitleyerek yürümek zorunda olan hastalarda, kalça abduktor zayıflığı nedeniyle valgus diz ile yürüyen ve mediyale kayma olan hastalarda bağ yetmezliğine bağlı instabilite daha sık görülür. Pes planus ile beraber tibialis posterior tendon zayıflığı olan hastalarda da, dizde benzer bir valgus dizilim gelişir iç yan bağ yetmezliğine bağı ınstabilite sık gözlenir.

Obez hastalarda cerrahi sırasında iç yan bağ tibial avulsiyonu sık görülmekte ve erken dönemde bunun klinik instabiliteye yol açtığı bilinmektedir.

Romatoid artrit gibi ilerleyici sinoviyal doku hastalıkları arka çapraz bağın yetmezliğine yol açarak instabilite nedeni olabilirken, patellektomi ya da yüksek tibial osteotomi öyküsü olan, aşırı fleksiyon kontraktürü olup, kontraktürün gevşetilmesi için arka çapraz bağ kısmi gevşetmesi yapılan hastalarda instabilite sık görülebilmektedir. Bu hastalarda posterior stabilize (PS) protezler tercih edilmelidir.

Tablo 1. Song ve ark.'nın total diz protezi sonrası instabilite sınıflandırması ${ }^{[4]}$

\begin{tabular}{|c|c|}
\hline Sınıflandırma & \\
\hline Fleksiyon/ekstansiyon aralık uyumsuzluğu & - $0^{\circ}, 15^{\circ}, 30^{\circ}, 60^{\circ}, 90^{\circ}$ hareket aralığında instabilite veya simetri \\
\hline Komponent pozisyonunun uygun olmayışı & $\begin{array}{l}\text { - Koronal planda }>5^{\circ} \text { açılanma } \\
\text { - Sagittal planda tibial eğim }<0^{\circ} \text { ya da }>10^{\circ} \\
\text { - Aksiyel planda femoral komponentin } 5^{\circ} \text { den fazla iç rotasyonu }\end{array}$ \\
\hline İzole bağ yetmezliği & $\begin{array}{l}\text { - Arka çapraz bağı koruyan protezlerde bağın kronik zayıflığı } \\
\text { - Mediyal veya lateral kollateral bağ yetmezlikleri }\end{array}$ \\
\hline Ekstansör mekanizmanın yetmezliği & $\begin{array}{l}\text { - Akut veya kronik patellar ya da kuadriseps tendon yaralanmaları } \\
\text { - Patella kırığı, çıkığı ya da patellar komponentin çıkığı }\end{array}$ \\
\hline Komponent gevşemesi & $\begin{array}{l}\text { - Gevşeme ile beraber komponentin pozisyonunun değişmesi (Grafilerde komponent çevresi } \\
2 \text { mm'den fazla görülen ve ilerleyici tipte radyolüsen hat, çimento hattında gözle görülür } \\
\text { kırıklar) }\end{array}$ \\
\hline Global instabilite & $\begin{array}{l}\text { - Koronal ve sagittal plan instabilitesinin bir arada görülmesi } \\
\text { - Polietilen aşınması veya kırılması ile beraber kronik sinovit, tekrarlayan hemartrozlar } \\
\text { - Polietilenin küçük boy seçilmesi } \\
\text { - En ağır tablo diz çıkığı }\end{array}$ \\
\hline
\end{tabular}


Poliomiyelit veya Charcot artropatisi ile instabil valgus dizi olan hastalarda erken dönem instabilite gelişme riski yüksek olduğu için, primer kısıtlı veya menteşeli protezler tercih edilebilir.

Total diz protezinde protez ara yüzleri ile doldurulacak eklem aralığını elde etmek için kemik ve yumuşak dokuda kesiler ve gevşetmeler yapıldıktan sonra ortaya çıkan eklem aralığının (gap) dizin hareket aralığı boyunca simetrik olması, tekniğe bağlı instabiliteyi arttırmamak için çok önemlidir. Burada oluşturulan boşlukların aynı kalınlıkta komponent ile doldurulması, yani dikdörtgen biçimde elde edilen boşluğun komponentler ile doldurulması sayesinde, yüzeyler arasındaki yük simetrik dağılacak ve diz stabil olabilecektir. Eğer aradaki bu boşluk (gap) trapezoid olursa, asimetrik yüke bağlı erken dönemde protezler arası ara yüzde (polietilen) ve kemik ile protez arasında (çimento veya direkt kemik temas alanı) bozulma, gevşeme ve dengesizlikler oluşur ve bu, instabilitenin en sık nedenlerinden biridir. Aralık asimetrisi durumunda, haftalar içinde klinik olarak instabilite bulguları ortaya çıkarken, geç dönem instabilitelerin çoğu aşınma ve gevşemeye bağlı olarak sonradan ortaya çıkan gap asimetrisine bağlıdır. ${ }^{[1-7,10,11]}$

\section{TEDAVi}

Fleksiyon ve ekstansiyonda, eklem aralığında simetrik veya asimetrik uyumsuzluklar ve buna bağlı instabilite gözlenebilir.

Kemik kesiler ve yumuşak doku gevşetmeleri ile elde edilen eklem aralığına ait boşluk dikdörtgen biçimde olup protezden daha geniş bir hacme sahipse, simetrik uyumsuzluktan bahsedilir. Bu durumda diz, uyumsuzluğun olduğu hareket aralığında koronal planda gevşektir. Bu tip instabilitenin nedeni, distal femoral ya da tibial kesinin fazla olmasıdır.

Tibial kesi fazla ise hem fleksiyonda hem de ekstansiyonda gevşeklik gözlenecek ve bu durum cerrahi sırasında fark edilirse kalın tibial insert ile giderilebildiği düşünülse de, eklem çizgisi aşağıya ineceği ve tibianın daha dar bir kısmına protez yerleşeceği için, uzun dönemde patellofemoral sorunlar (eklem çizgisine bağlı) veya tespit sorunları (daha dar tibial yüzeye protez tespiti) ortaya çıkabilecektir.

Distal femoral kesinin fazla olmasına bağlı uyumsuzlukta da hem fleksiyon hem ekstansiyonda gevşeklik gözlenirken, kalın insert ekstansiyonda gevşekliği giderirken fleksiyonda artmış sıkılığa bağlı fleksiyon kısıtlılığı ortaya çıkacak ve eklem çizgisi yükseleceği için, kollateral bağ etkin mesafesi azalarak midfleksiyon instabilitesi ortaya çıkabilecek, yine patellofemoral uyum bozulacaktır. Bu nedenle, simetrik ekstansiyon uyumsuzluğu aşırı femoral kesiye bağlı ise buna yönelik olarak fazla kesiyi düzeltmek üzere distal femoral augment kullanılmalıdır.

Ekstansiyon aralığında simetrik uyumsuzluk ile görülebilen instabilitelerden bir diğeri de rekurvatum veya hiperekstansiyon instabilitesidir. Tibial kesinin veya distal femoral kesinin fazla olduğu durumlarda cerrahi sırasında hiperekstansiyon görülebilmekle beraber, bu durum sıklıkla ekstansör mekanizmanın zayıflığında ortaya çıkar. Ameliyat öncesi kuadriseps zayıflı̆̆ı olan hastalar dizlerini kilitlemek için hiperekstansiyonda yürüdükleri için ortaya çıkan rekurvatum dizilim, ameliyat sonrası devam ederek bir hiperekstansiyon instabilitesi olarak ortaya çıkabileceği gibi, primer diz protezi sırasında aşırı kollateral bağ gevşekliği kalan dizlerde de rekurvatum instabilitesi gelişme riski yüksektir. Kısalmış iliotibial bant ile beraber sabit diz valgus deformitesi bulunan hastalarda ve bağ instabilitelerinin görüldügü romatoid artritte de rekurvatum instabilitesi görülebilir. Bu dizlerde, protez için yapılan distal femoral kesi az tutularak ya da distal femoral augment kullanarak, ekstansiyon aralığı dar tutulup bilinçli bir fleksiyon kontraktürü sağlanarak, hiperekstansiyon instabilitesinin önüne geçilebilir. Krackow ve Weiss tarafından tanımlanan kollateral bağların femoral origosunun, ekstansiyonda gerginliğini arttırmak için, proksimal ve posteriora taşınması da hiperekstansiyon instabilitesinin çözümü için tanımlanmış yöntemlerden biridir. Literatürde, total diz protezi ameliyatı yanında yapılacak diz bağ girişimleri ve özellikle bağ gevşetmeleri dışında kalan tamir, augmentasyon ve ilerletmeler yeterince kabul görmemiş ve sonuçları açısından güvenilmez kabul edilmiştir. Bu tür yumuşak doku girişimlerinden çok, hareketi kısıtlayan tipte protez kullanarak stabilite sağlayan santral kısıtlı tasarımlar (Central Constrained Condylar -CCK) veya menteşeli diz protezleri kullanılması önerilmektedir. Menteşeli protezler daha çok revizyon sırasında tercih edilir; ancak, baş edilemeyen instabilitelerin çözümleri arasında artrodezi de akılda tutmak gerekir.

Bağ dengesinin sağlanamamasına bağlı ortaya çıkan, oluşturulan eklem aralığının trapezoidal olduğu uyumsuzluklar, asimetrik uyumsuzlukların en sık nedenidir. Asimetrik uyumsuzluk, ameliyat öncesi deformitelere bağlı bağ gevşeklikleri veya ameliyat sırasında yumuşak doku dengesi için yapılan gevşetmelerde yetersiz ya da fazla gevşetmeye bağlı ortaya çıkabilir; en sık ekstansiyonda gözlenir.

Varus dizlerde mediyal kollateral bağ gergin ve kısalmışken, lateral kollateral bağ normal gerginliktedir. Sıklıkla bağın bütünlüğünün bozulmasından çekinmeye bağı ıetersiz mediyal gevşetme yapılan dizlerde, mediyal aralık dar ve sıkı kalırken dış yan bağ göreceli 
olarak gevşek kalacağından, varus instabilitesi ortaya çıkabilir. Insall ve ark.'nın tanımladığı şekilde, pes anserin tendonlar sağlam kalacak şekilde ve uzun bir yumuşak doku kılıfı bırakılarak yeterli mediyal gevşetme yapılmalı ve mediyale konulacak elevatörlerin mediyal kollateral bağa zarar vermesinden kaçınılmalıdır. Mediyal gevşetmenin yeterli miktarı ile ilgili Matsuda ve ark. ${ }^{[12]}$, mediyal komponent aralığında $1 \mathrm{~mm}$ 'den fazla boşluk oluşacak şekilde protez uygulanan dizlerde fleksiyon kontraktürü görülmezken 3 mm'ye kadar hareket varlığında bile instabilite gelişmediğini, nötral dizilim elde edildiği sürece ekstansiyonda 5 mm'ye kadar ortaya çıkan gevşeklik ile "lift-off” gözlenmediğini bildirmişlerdir. ${ }^{[4,13]}$

Valgus dizlerde ise mediyal kollateral bağ gevşek olduğu için, yeterli açısal düzeltme yapılıp yeterli lateral gevşetme yapılmazsa, gerekli mediyal sıkılık elde edilemediğinden valgus deformitesi tekrar eder. Lateral gevşetmenin yeterli ve güvenli yapılabilmesi için Insall ve ark., pie-crust (turta deseni) gevşetme tekniğini tanımlamışlardır. Mediyal gevşekliğe bağlı ortaya çıkan instabilitenin görüldügü valgus dizlerde, mediyal kollateral bağın gevşekliği sadece çok az miktarda ise kabul edilebilir. ileri yaştaki hastalarda, $20^{\circ}$ 'den fazla valgus varsa açısal düzeltme sırasında lateral tarafta aşırı uzamaya bağlı peroneal sinir hasarı oluşturmamak adına, düzeltmenin daha az yapıldığı kısıtlayıcı bir protez sistemi tercih edilirse sinir hasarı önlenir. İleri yaştaki günlük yaşam aktivitelerinin nispeten az olması nedeniyle de kısıtlayıcı proteze ait protez kemik aralığında artmış yüklere bağlı erken revizyon riski oluşmayacaktır. İleri valgus deformitelerde, lateral femoral kondil osteotomisi ile posterior veya distale ilerletme ve tespit ile de stabil başarılı protez sonuçları bildirilmiştir. ${ }^{[5,6,12]}$

Yetersiz kemik kesisi yapılan olgularda ameliyat sırasında agresifvarus-valgus testleri sırasında, femoral ya da tibial kesilerin uygun olmayan planlarda veya yükseklikte yapılmasına bağlı, agresif ekartasyonla, diz eklemine aşırı fleksiyon pozisyonunda yaklaşmaya bağlı olarak, obez hastalarda disseksiyon ve ekartasyon sırasında oluşan iyatrojenik bağ yaralanmaları da instabiliteye yol açabilir. Bu durumda; bağın primer tamiri, hamstring tendonlar ile güçlendirilmesi ve/ veya kısıtlayıcı protezlere geçilmesi çözümler arasında yer alır. Torre ve ark.'nın literatür değerlendirmesi göstermektedir ki, bağın güçlü tamirinin yapılamadığı ileri yaştaki olgular dışında, çoğu kez güçlendirme ile beraber veya tek başına primer tamir yanında sadece posterior stabilize (PS) insert ile iyi sonuçlar elde edilmektedir. Direkt tamir sonrası 4-6 hafta menteşeli dizlik ile stabil iyileşme sağlanabilmektedir. Yarı kısıtlı menteşesiz veya menteşeli protezler, ileri yaştaki hastalarda tercih edilmelidir. ${ }^{[13]}$
İyi dizilimi olan ve iyi sabitlenmiş protezlerde, fleksiyon boşluğunu protez yeterince dolduramazsa fleksiyon instabilitesi ortaya çıkacaktır. Fleksiyon boşluğunun sınırlarını esas belirleyen, posterior femoral kondiller kesilerdir. Fleksiyonda ortaya çıkan instabilitelerde hasta, çoğu kez fleksiyonda yük verme ile ortaya çıkan, tibia metafizine kadar uzanan anteromediyal eklem ağrısı ile başvurur. Merdiven iner-çıkarken ve oturma pozisyonundan ayağa kalkarken artan ağrı ve güvensizlik yanında, tekrarlayan sinovit atakları ile effüzyonlar fleksiyon instabilitesinde tipiktir. Fleksiyon instabilitesinin nadir görülen en ağır şekli ise diz çıkı̆̆ı$\operatorname{dır}\left(\% 0,5^{\prime}\right.$ in altında). ${ }^{[1,2]}$

Fleksiyon instabilitelerinde, $90^{\circ}$ fleksiyonda yapılan koronal stabilite ve ön arka çekmece muayenelerinde, esneklik veya asimetrik açılma olarak kendini gösterir. Doksan derecede koronal planda lateral açılmanın $4^{\circ}$ 'den fazla olduğu olgularda femoral komponentin iç rotasyonda olduğu, Romero ve ark.'nın floroskopi ve BT çalışmasında gösterilmiştir. ${ }^{[14]}$ Bu hasta grubunda tırmanma ve oturduğu yerden kalkmanın ağrılı olduğu, derin duyunun azaldığı klinik olarak gösterilmiş̧tir. Fleksiyonda ön-arka instabilite arka femoral boşluğun simetrik genişliğine bağlıyken, koronal planda instabilite femoral komponentin yanlış rotasyonuna bağIı olarak ortaya çıkan asimetrik fleksiyon aralığından kaynaklanır. Benzer şikâyetleri olan diğer bir hasta grubunda da, koronal plan simetrik iken $90^{\circ}$ fleksiyonda ön-arka çekmece testlerinde esneme aşırıdır. Sagittal plandaki bu aşırı esnemenin nedeni; arka çapraz bağın korunduğu protezlerde bağa ait akut ya da kronik arka çapraz bağ patolojileri, posterior femoral offset yetersizliği, tibial eğimin normalden fazla olması ya da posteromediyal insert aşınması olabilir. Arka çapraz bağın korunduğu protezlerde, posterior femoral kondil kesisi ve yerleştirilen protezin posterioruna ait "offset"in ameliyat öncesi lateral grafidekinden az olmamasına dikkat edilmelidir. Posterior stabilize protezlerde de femoral offset kaybedilirse, fleksiyon aralığındaki boşluk instabilite olarak kendisini gösterecektir. ${ }^{[1,2,4]}$

Nadir görülen ancak en ağır fleksiyon instabilitesi tablosu ise diz protezinin çıkığıdır. Fleksiyonda varus zorlanması ile ortaya çıkan çıkıklarda öykü, etkilenen tarafın ayakkabısını bağlamak için oturur pozisyonda iken ayağı diğer dizin üzerine koyma sonrası ani ve çok ağrılı deformitedir (Şekil 2). Arka çapraz bağın korunduğu protezlerde, bağa ait kısmi yırtıklar veya yetmezlik ameliyat sırasında fark edilmezse, erken dönemde giderek, fleksiyonda ön-arka gevşeklikte artış gösteren fleksiyon instabiliteleri gelişebileceği gibi, aşırı valgus dizlerde agresif lateral gevşetmeler sonrası da fleksiyon instabilitesi ortaya çıkabilir. Gevşetmeler tamamlandıktan sonra, Figür-4 pozisyonuna getirilen dizin 


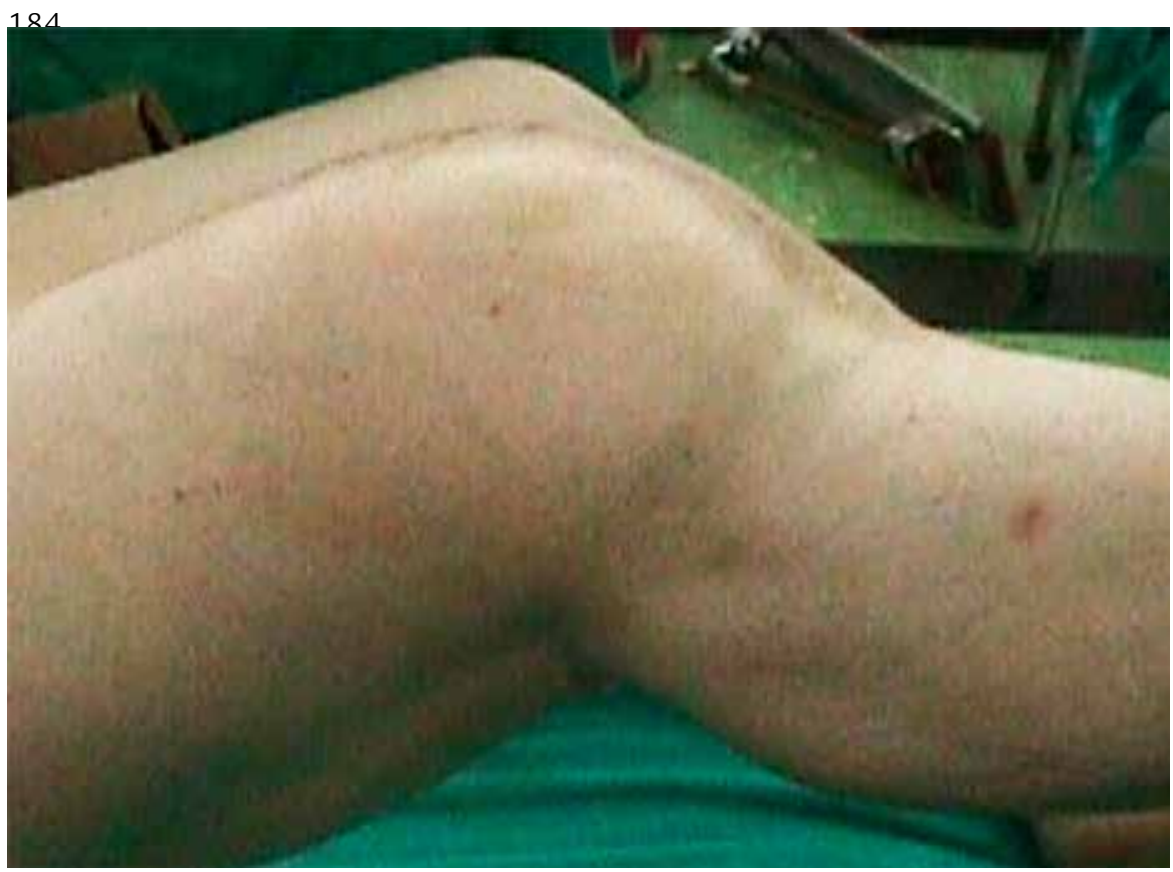

Şekil 2. Diz protezi sonrası diz çıkığı.

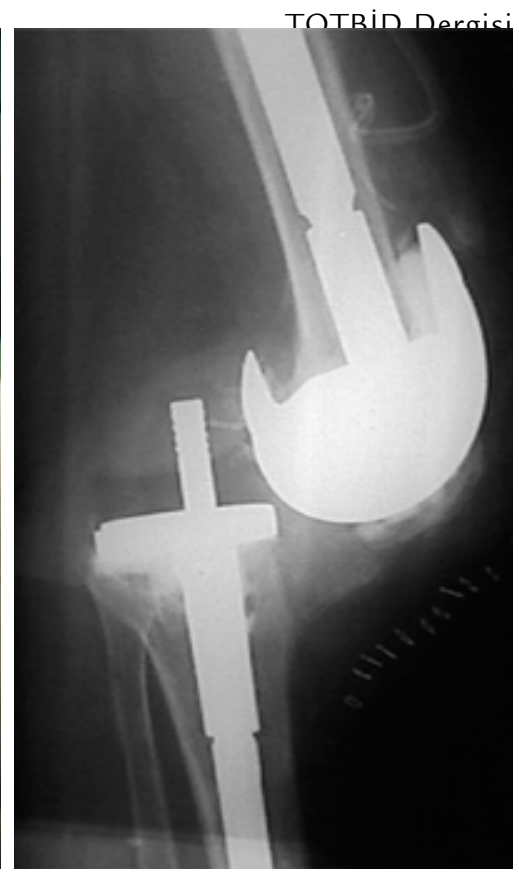

Şekil 3. Fleksiyon instabilitesi olan total diz protezli olguda posterior sag bulgusu. stabilitesi değerlendirilip, uygun kalınlıkta insert seçilmelidir. Posterior stabilize protezlerde sagittal plan hareketlerde ekstansiyonda ve erken fleksiyonda tibial post femoral komponenti tutarak arka çıkığa engel olabilse de ileri fleksiyon ile beraber varus/valgus hareketi veya rotasyon, post atlama mesafesini aşmaya yol açarak çıkık ile sonuçlanabilir. Diz protezi sonrası çıkıklar anestezi altında kapalı redüksiyon sonrası dizlik ile tedavi edilebilir. Tekrarlayan çıkıklarda ise revizyon cerrahisi kaçınılmazdır. Revizyonda fleksiyon aralığının uygun şekilde oluşturulması için tüm komponentlerin gözden geçirilmesi gerekmektedir. ${ }^{[1,2,5]}$

Arka çapraz bağın korunduğu protezlerde de fleksiyon boşluğunun yeterli sıkılıkta olmaması hastalarda benzer şikâyetler ortaya çıkarır. Tipik muayene bulgusu, hastanın kalça ve dizi $90^{\circ}$ 'de tutarken ayak bileğinden desteklendiğinde yer çekimine karşı ortaya çıkan, sakin otururken ise arka çekmece manevrası ile ortaya çıkan tibiada arkaya esneme (posterior sag) bulgusudur (Şekil 3 ). Bu protezlerde instabiliteye neden olan olası cerrahi teknik hatalar, femoral komponentin normalden küçük yerleştirilmesi ve gereğinden fazla tibial eğimdir. Ayrıca, sonradan ortaya çıkan arka çapraz bağın bütünlük kaybı inflamatuvar veya posteromediyal gevşetmenin yetersizliğine bağlı polietilen aşınması sonrası sinovit ve artmış fleksiyon aralığı da geç dönem instabilite nedenleri arasında sayılır. Dahası, fleksiyon aralığı başlangıçta sıkı olan hastalarda rehabilitasyon sırasında ani rahatlama ile kendini gösteren arka çapraz bağın yırtılması da geç dönem instabilite nedeni olabilir.
Fleksiyon instabilitelerinde kuadriseps ve hamstring güçlendirmeler ile tedavi bir alternatif olmakla beraber, fleksiyon aralığının tekrar doğru şekilde oluşturulması için revizyon cerrahisi planlanmalıdır. Sadece posterior stabilize insert ile revizyon kolay bir seçenek olarak görülmekle beraber, uzun dönem sonuçları belirsizdir. İdeal çözüm, femoral komponentin büyütülerek boşluğun posterior femoral augment ile doldurulması ve tibial eğimin gözden geçirilerek gerekirse revize edilmesidir. ${ }^{[1,2,5]}$

Son yıllarda, fleksiyon instabilitelerinin mekanizmaları araştırılırken, midfleksiyon instabilitesinin farkına varılmıştır. Dizin $30-60^{\circ}$ hareket alanında koronal ve sagittal boşluğun fazla olmasına bağlı ortaya çıkan bu fleksiyon instabilitesinde, diğer fleksiyon instabilitelerinde olduğu gibi, sıkça ön diz ağrısı ve oturduğu yerden kalkmada zorlanma görülür. Ramappa ve ark.'nın literatür değerlendirmelerinde, midfleksiyon instabilitesi için öne sürülen nedenler arasında, fleksiyon kontraktürünü düzeltmek için yapılan fazla distal femoral kesiye bağlı yükselen eklem çizgisi vardır. Eklem çizgisinin yükselmesi ile beraber kollateral bağlarına yapışma çizgisinin konumu değişecek, etkinliği azalacak ve posterior kapsül fleksiyon hareketi başlarken gevşekleşme de başlayacaktır. Ancak, bu teoriyi destekleyen çalışma sadece kadavra çalışmasıdır. Bir diğer çalışmada, multiradius protez tiplerinde midfleksiyon instabilitesinin görüldüğü bildirilmiştir; bu çalışmaların da sayısı oldukça azdır. Valgus dizlerde olduğu gibi, mediyal kollateral bağ gevşekliğinin 
olduğu dizlerde de, bu gevşekliğin midfleksiyon instabilitesine yol açtığı bilinmektedir. ${ }^{[14]}$ Vince de midfleksiyon instabilitesi ile ilgili literatür desteğinin az olduğunu savunmuş ve düzeltilmeyen fleksiyon kontraktürü gibi ekstansiyonda gergin olan arka kapsülün fleksiyon hareket aralığına girilmesi ile beraber fazla gevşediği durumlarda bu tip bir instabilitenin ortaya çıkabileceğinden bahsetmiştir. ${ }^{[10]}$

\section{SONUÇ}

Diz protez revizyonlarının erken dönemde en sık ikinci nedeni instabilitedir. Instabilitenin ortaya konması ve nedeninin anlaşılabilmesi için hastanın öyküsü ile beraber tüm klinik değerlendirmesinin dikkatli bir şekilde yürütülmesi gerekmektedir. Diz ekleminin her hareket aralığında koronal ve sagittal stabilitesi değerlendirilmeli ve bu değerlendirmeler floroskopi veya direkt grafiler ile görüntülenmelidir. BT, ekstremitenin ve komponentlerin rotasyonlarını değerlendirmede ve instabilitenin nedenini anlamada oldukça önemlidir.

Cerrahi teknik sırasında ekstremitenin dizilimi, kemik kesiler ve yumuşak doku gevşetmeleri ve/veya sıkılaştırmaları, güçlendirmeleri arasında iyi bir denge sağlanmalı, böylece simetrik bir eklem aralığı elde edilmelidir. Önceden var olan ve instabiliteye yatkınlığı arttıran ağır deformiteler, eklem dışı deformiteler, obezite, nöromusküler yetmezlikler ya da bağ yetmezlikleri akılda tutulmalı ve bunlara uygun protezler ve teknikler tercih edilmelidir.

İnstabilite nedeniyle yapılan revizyonlar sonrası düzeltilemeyen instabilite oranlarının yüksek olma nedeninin, hastadaki instabilitenin tanımı ve nedeninin tam ve doğru yapılamamasından kaynaklandığı unutulmamalı, gerçek probleme yönelik kalıcı çözümler üretilmelidir. Revizyon cerrahilerinde eklem çizgisinin korunması ve yeniden oluşturulması konusunda oldukça titiz davranmalı ve yeterli olan en az kısıtlı protez tercih edilmelidir.

\section{KAYNAKLAR}

1. Del Gaizio DJ, Della Valle CJ. Instability in Primary Total Knee Arthroplasty. Orthopedics 2011;34(9):e519-21. Crossref

2. Rodriguez-Merchan EC. Instability Following Total Knee Arthroplasty. HSS J 2011;7(3):273-8. Crossref

3. Mulcachy H, Chew FS. Current Concepts in Knee Replacement: Complications -Musculoskeletal Imaging- Review. AJR Am J Roentgenol 2014;202(1):W76-86. Crossref

4. Song SJ, Detch RC, Maloney WJ, Goodman SB, Huddleston JI 3rd. Causes of Instability After Total Knee Arthroplasty. J Arthroplasty 2014;29(2):360-4. Crossref

5. Parratte S, Pagnano MW. Instability After Total Knee Arthroplasty. J Bone Joint Surg Am 2008;90(1):184-94.

6. Yercan HS, Ait Si Selmi T, Sugun TS, Neyret P. Tibiofemoral instability in primary total knee replacement: A review, Part 1: Basic Principles and classification. Knee 2005;12(4):257-66. Crossref

7. Yercan HS, Ait Si Selmi T, Sugun TS, Neyret P. Tibiofemoral instability in primary total knee replacement: A review, Part 2: Diagnosis, patient evaluation and treatment. Knee 2005;12(5):336-40. Crossref

8. Donaldson J, Joyner J, Tudor F. Current Controversies of Alignment in Total Knee Replacements. Open Orthop J 2015;9(Suppl 2):489-94. Crossref

9. Thomas AD, Mandalia V, Haigh R, Hopwood B. The Management of Patients with Painfull Total Knee Arthroplasty. J Bone Joint Surg Br 2009;91-B(2):143-50. Crossref

10. Vince K. Mid-flexion instability after total knee arthroplasty. Wooly thinking or a real concern. Bone Joint J 2016;98-B(1 Suppl A):84-8. Crossref

11. Easley ME, Insall JN, Scuderi GR, Bullek DD. Primary constrained condylar knee arthroplasty for the arthritic valgus knee. Clin Orthop Relat Res 2000;380:58-64. Crossref

12. Matsuda S, Ito $H$. Ligament balancing in total knee arthroplasty - Medial stabilizing technique. Asia-Pacific J Sports Med 2015;2(4):108-13. Crossref

13. Torre PD, Stephens A, Oh HL, Kamra A, Zicat B, Walker P. Management of Medial Collateral Ligament Injury During Primary Total Knee Arthroplasty: A Systematic Review. Reconst Rev 2014;4(2):17-23. Crossref

14. Romero J, Stahelin T, Binkert C, Pfirrmann C, Hodler J, Kessler O. Clinical Consequences of Flexion Gap Asymmetry in Total Knee Arthroplasty. J Arthroplasty 2007;22(2):23540. Crossref 